\title{
Optimization of Fertilizer Recommendations for Bread Wheat at Sinana District of Bale Zone, Southeastern Oromia, Ethiopia
}

\author{
Mulugeta Eshetu*, Shure Sebboka, Tilahun Chibsa, Chala Chimdessa, Negash Bedasso \\ Sinana Agricultural Research Center, Soil Fertility Improvement, Soil and Water Conservation Team Oromia Agricultural Research Institute \\ (OARI), Addis Ababa, Ethiopia
}

Email address:

mulugeteshetu@gmail.com (M. Eshetu)

${ }^{*}$ Corresponding author

To cite this article:

Mulugeta Eshetu, Shure Sebboka, Tilahun Chibsa, Chala Chimdessa, Negash Bedasso. Optimization of Fertilizer Recommendations for Bread Wheat at Sinana District of Bale Zone, Southeastern Oromia, Ethiopia. International Journal of Science and Qualitative Analysis. Vol. 3, No. 6, 2017, pp. 55-60. doi: 10.11648/j.ijsqa.20170306.11

Received: October 15, 2017; Accepted: January 22, 2018; Published: January 23, 2018

\begin{abstract}
A field experiment was conducted during the "Bona" season of 2016 at Bale highland agro ecology and environment to optimizing fertilizer rate recommendation for major cereal production systems by using wheat as test crop. Experiment was laid out in a randomized complete-block (RCBD) design with three replications for sixteen (16) treatments were conducted. It was found that the amount of $\mathrm{N}$ application in plants had significant difference between treatments applied with nitrogen fertilizer. The grain yield and yield components were all elevated remarkably by applying different rate and type of fertilizer; four level of $\mathrm{N}(0,23,46,69,92)$ three levels of $\mathrm{P}(0,10,20)$, and three level of $\mathrm{K}(0,10,20)$ in addition the last three treatment foliar application 45 days after planting and comparing with control (absolute zero) treatment. There was significant difference in grain yield and yield components of Madda walabu (bread wheat) among the treatments. The results showed in addition to significant difference among the treatments, high yield response recorded under $46 \mathrm{~N}-20 \mathrm{P}-0 \mathrm{~K}-0 \mathrm{~S} \mathrm{~kg} \mathrm{ha}{ }^{-1}\left(5,3 \mathrm{t} \mathrm{ha}^{-1}\right)$ and followed by $69 \mathrm{~N}-20 \mathrm{P}-0 \mathrm{~K}-0 \mathrm{Skg} \mathrm{ha} \mathrm{h}^{-1}\left(4.5 \mathrm{t} \mathrm{ha}^{-1}\right)$ the lower yield response was under control treatment $\left(2.3 . \mathrm{t} \mathrm{ha}^{-1}\right)$. In

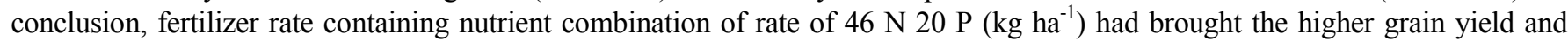
showed efficient use of fertilizer combination. The result indicted that the optimum fertilizer applications for bread wheat $46 \mathrm{~N} 20$ $\mathrm{P}\left(\mathrm{kg} \mathrm{ha}^{-1}\right)$ were brought maximum yield for selka site of sinana district.
\end{abstract}

Keywords: Nutrient Type and Rate, Madda Walabu varities, Grain Yield

\section{Introduction}

Wheat (Triticum aestivum L.) is the most important cereal crop in the world and is the staple food for humans. Nitrogen is the most limiting nutrient for wheat production that affects the rapid plant growth and improves yield and yield component of wheat. Many researches showed that $\mathrm{N}$ application increased grain yield (GY) of wheat. [5], concluded that number of fertile tiller per unit area, number of grain per spike (NGS), and harvest index were significantly increased by increasing $\mathrm{N}$ fertilization levels. [12], reported that nitrogen efficiency indices were significantly affected by $\mathrm{N}$ fertilizer rates. Reduction of applied $\mathrm{N}$ fertilizer rate to an optimized level can reduce soil nitrate leaching [13]. Although nitrogen is the key nutrient in increasing productivity and the increase of agricultural food production worldwide over the past four decades has been associated with a 7-fold increase in the use of $\mathrm{N}$ fertilizers [14]. Therefore, ideal nitrogen management optimizes yield, farm profit and nitrogen use efficiency while minimizing the potential for leaching of nitrogen beyond the crop rooting zone [15]. [10], reported that genotype and soil fertility are important factors affecting the production of wheat with high yield and protein content when soil moisture and weather conditions are favorable. He indicated that fertilizers, particularly those containing $\mathrm{N}$ and $\mathrm{P}$ are the major inputs affecting wheat grain yield and quality. In line with this, Tilahun (1994) and [3], revealed that $\mathrm{N}$ and $\mathrm{P}$ are the two 
most essential plant nutrients often limiting the yield and growth of wheat crop. Under most field conditions, the amounts of soluble and readily mineralized soil $\mathrm{N}$ are insufficient to meet the crop requirement. Therefore, to obtain better growth of high yielding crops, $\mathrm{N}$ as chemical fertilizer, manure, crop residue, or other source, must be added. [6], also reported that increased usage of $\mathrm{N}$ fertilizer is considered as one of the primary means of increasing wheat grain yield in Ethiopia. Therefore, determination of optimum $\mathrm{N}$ and $\mathrm{P}$ fertilizer rates is critical for economic production and productivity of wheat crop ([6]; [4]). Therefore, determination of optimum rates and evaluating different source fertilizers and thereby improving the yield of bread wheat and soil fertility for sound management of the soil resource base are of paramount importance. Therefore, the present investigation was undertaken for the following objectives; to optimizer fertilizer recommendations for these crops and determine yield with different levels for each nutrient of interest and to obtain the information needed to determine robust nutrient response functions.

\section{Materials and Methods}

\subsection{Description of the Study Area}

The study was conducted in Sinana district of Selka Oda site in 2016 cropping season. The area has bimodal rainfall pattern with the first rainy season starting in March and taper off in July, while the second rains fall between August and December. Topographically, the area consists of gently undulating plain with average slope gradient of $6 \%$. Crop production in the study area is characterized by cereal dominated cropping system. Wheat is extensively grown followed by barley. Some highland pulses such as field pea, faba bean, and oil crops like mustard and linseed are also grown.

\subsection{Experimental Design and Treatment Application}

Experiment was laid out in a randomized complete-block design (RCBD) in three replications that contained 16 treatments of different plant nutrient combinations (Table 1). The last 3 treatments $(14,15 \& 16)$ were diagnostic treatments containing as micro nutrients Sulfur $(\mathrm{S})$, Zinc $(\mathrm{Zn})$, Magnesium $(\mathrm{Mg})$, and Boron $(\mathrm{B})$ were used from fertilizer source $\mathrm{CaSO}_{4} \cdot 2 \mathrm{H}_{2} \mathrm{O}, \mathrm{ZnSO}_{4}, \mathrm{MgSO}_{4} \cdot 7 \mathrm{H}_{2} \mathrm{O}$ and Borax respectively. NPKS were applied at planting from sources like Urea, TSP, $\mathrm{Kcl}$ and calcium sulphate, respectively. Micronutrients were applied as a foliar application after 45 days of germination in 2016 cropping season. The all experiment treatments were applied on specified plot size, plant spacing using bread wheat (Madda Walabu varties) as test crop, each treatment was applied on a plot size of $2.5 \mathrm{~m} \mathrm{x}$ $2 \mathrm{~m}=5 \mathrm{~m}^{2}$, the distance between blocks and within plots are $1 \mathrm{~m}$.

\subsection{Data Collection and Statistical Analysis}

Grain yield data was collected and adjusted at $12.5 \%$ Moisture Content. It was subjected to analysis of variance (ANOVA) using the GLM procedure of SAS statistical package version 9.0 (SAS Institute inc.,), 2002). The List Significant Difference using fisher's LSD test at 5\% level of significance was used to identify differences among the means.

Table 1. List of Treatments.

\begin{tabular}{|c|c|c|c|c|c|c|c|}
\hline \multirow{2}{*}{ Treatment } & \multicolumn{7}{|c|}{ Nutrients rate $\left(\mathrm{kg} \mathrm{ha}^{-1}\right)$} \\
\hline & $\mathbf{N}$ & $\mathbf{P}$ & $\mathbf{K}$ & $\mathbf{S}$ & Zn & Mg & B \\
\hline $\mathrm{T} 1=$ Control $(0,0,0)$ & 0 & 0 & 0 & 0 & 0 & 0 & 0 \\
\hline $\mathrm{T} 2=23 \mathrm{~N}$ & 23 & 0 & 0 & 0 & 0 & 0 & 0 \\
\hline $\mathrm{T} 3=46 \mathrm{~N}$ & 46 & 0 & 0 & 0 & 0 & 0 & 0 \\
\hline $\mathrm{T} 4=69 \mathrm{~N}$ & 69 & 0 & 0 & 0 & 0 & 0 & 0 \\
\hline $\mathrm{T} 5=92 \mathrm{~N}$ & 92 & 0 & 0 & 0 & 0 & 0 & 0 \\
\hline $\mathrm{T} 6=20 \mathrm{P}$ & 0 & 20 & 0 & 0 & 0 & 0 & 0 \\
\hline $\mathrm{T} 8=46 \mathrm{~N} 20 \mathrm{P}$ & 46 & 20 & 0 & 0 & 0 & 0 & 0 \\
\hline $\mathrm{T} 9=69 \mathrm{~N} 20 \mathrm{P}$ & 69 & 20 & 0 & 0 & 0 & 0 & 0 \\
\hline $\mathrm{T} 10=92 \mathrm{~N} 20 \mathrm{P}$ & 92 & 20 & 0 & 0 & 0 & 0 & 0 \\
\hline $\mathrm{T} 11=92 \mathrm{~N} 10 \mathrm{P}$ & 92 & 10 & 0 & 0 & 0 & 0 & 0 \\
\hline $\mathrm{T} 12=92 \mathrm{~N} 20 \mathrm{P} 20 \mathrm{~K}$ & 92 & 20 & 20 & 0 & 0 & 0 & 0 \\
\hline $\mathrm{T} 13=92 \mathrm{~N} 30 \mathrm{P}$ & 92 & 30 & 0 & 0 & 0 & 0 & 0 \\
\hline $\mathrm{T} 14=92 \mathrm{~N} 20 \mathrm{P} 10 \mathrm{~K} 2.5 \mathrm{~S}, 0.5 \mathrm{Zn}, 2.5 \mathrm{Mg}, 0.5 \mathrm{~B}$ & 92 & 20 & 10 & 2.5 & 0.5 & 2.5 & 0.5 \\
\hline
\end{tabular}

\subsection{Nutrient Response Curve and Net Return Curve Development}

The net return curve was developed from yield predicted by the selected response curve with the consideration of wheat price at harvesting time and nutrient cost at planting. Price of Wheat was assumed to be $6.50 \mathrm{ETB} / \mathrm{kg}$. Assuming cost of DAP at planting was $1740.00 \mathrm{ETB}$ and that of Urea was $1400.00 \mathrm{ETB}$, the cost of the nutrients would be 30.4 $\mathrm{ETB} / \mathrm{kg} \mathrm{N}$ and $59.64 \mathrm{ETB} / \mathrm{kg}$ P. Partial budget analysis was done by adjusting the yield down by $10 \%$ to select the optimum nutrient combinations for bread wheat in the study area (CIMMYT, 1988).

$$
\mathrm{Y}=\mathrm{a}-\mathrm{b} * \mathrm{c}^{\mathrm{X}} \text { Where, } \mathrm{Y}=\text { predicted grain yield }(\mathrm{kg} / \mathrm{ha})
$$


$\mathrm{a}=$ maximum achievable yield $(\mathrm{kg} / \mathrm{ha})$

$\mathrm{b}=$ slope

$\mathrm{c}=$ coefficient and

$\mathrm{X}=$ Nutrient rate

After the three coefficients was determined by using Statistix 10 software mean of the treatments from the trial, the best representative coefficient was selected for the study area by visual observation of prediction graph of mean.

\section{Results and Discussion}

\subsection{Effect of Different Nutrient Types and Rates on Yield and Yield Component of Bread Wheat}

The application of different nutrient type and rate exerted a significant $(p \leq 0.05)$ positive influence on the growth and yield attributes, and yield of wheat as given in (Table 2), as the rate of $\mathrm{N}$ reduced the plant height, number of tiller, spike length and number of seed per spike also decrease. Bread Wheat grain (Madda Walabu varities) response for applied different nutrient types and rates of fertilizer show significant differences. From the Results in addition to significant difference among the treatment, high yield response $(5.3 \mathrm{t} \mathrm{ha}$ $\left.{ }^{1}\right)$ recorded under (46-20-0-0) rate of N-P-K-S (Kgha $\left.{ }^{-1}\right)$ and followed by yield (4.5 $\left.\mathrm{t} \mathrm{ha}^{-1}\right)$ advantage under (69-20-0-0) rate of N-P-K-S $(\mathrm{Kg} / \mathrm{ha})$ the lower yield response was under control (0-0-0-0 rate of N-P-K-S $\left(\mathrm{Kgha}^{-1}\right)$ treated plot $(2.1 \mathrm{t}$ $\left.\mathrm{ha}^{-1}\right)$. From the result indicate that Application of nitrogen (N) fertilizer is one of the most important measures that increases grain yield of wheat (Triticum aestivum L.) production. The results of an experiment conducted by [11] in Pakistan involving four wheat varieties indicated that application of different rates of $\mathrm{N}$ fertilizer had significantly affected biological yield, grain yield, grain protein content and many other selected yield components. Several studies in Ethiopia [16] have also demonstrated the role of $\mathrm{N}$ in wheat production in the highlands and hence substantial changes in yield and yield components have been observed with the application of $\mathrm{N}$ fertilizer. Moreover, application of different levels of $\mathrm{N}$ to wheat crop on Vertisols and Nitisols in the Central Highlands of Ethiopia had significantly increased grain and biomass yields [3] and grain and straw $\mathrm{N}$ contents [2]. The result indicated that $\mathrm{N}$ promotes rapid growth and increases tiller production and consequently results in increases in grain yield. Similarly, [8], confirmed that the number of tillers per plant increased with increasing the rate of $\mathrm{N}$ to an optimum level. [7], also indicated that lower $\mathrm{N}$ rates have been shown to result in reduced number of tillers, and lower tillers number was associated with reduced yield. The Result indicate that the use of phosphorus with $92 \mathrm{~kg} / \mathrm{ha}$ nitrogen was not significantly affected bread wheat grain yield and economically not feasible. Similarly, effect of the other nutrient like $\mathrm{K}, \mathrm{S}, \mathrm{Zn}, \mathrm{Mg}$ and $\mathrm{B}$ used in these experiments were significant difference on grain yield and yield component of bread wheat as compare to the control (no fertilizer) but no significance difference in some yield parameter among them. The result indicated that among different nutrient rate and type in addition with micro nutrient as foliar application treatment contend $92 \mathrm{~N}-20 \mathrm{P}-30 \mathrm{~K} 7.5 \mathrm{~S}$ $1.5 \mathrm{Zn}-7.5 \mathrm{Mg}-1.5 \mathrm{~B}$ better yield as compared to the other. However, the significant yields were not economically feasible as compared to other treatment as well as the control. Therefore, treatments containing these nutrients were not considered in further analysis like nutrient response and net return curve development.

Table 2. Effect of Fertilizer (s) Type and Rate on wheat Grain Yield in Sinana District in 2016.

\begin{tabular}{|c|c|c|c|c|c|c|c|}
\hline Treatments & PH (cm) & SL (cm) & $\mathbf{S} / \mathbf{S}$ & NT & BM $\left(\mathrm{t} \mathrm{ha}^{-1}\right)$ & Gy $\left(\mathrm{t} \mathrm{ha}^{-1}\right)$ & TKW \\
\hline $0 \mathrm{~N}-0 \mathrm{P}-0 \mathrm{~K}-0 \mathrm{~S}$ & $70.9^{d}$ & $6.8^{\mathrm{d}}$ & $23.5^{d}$ & $4.1^{\mathrm{bc}}$ & $8.3^{\mathrm{bc}}$ & $2.1^{\mathrm{j}}$ & $239.8^{\mathrm{ba}}$ \\
\hline $23 \mathrm{~N}-0 \mathrm{P}-0 \mathrm{~K}-0 \mathrm{~S}$ & $77.9^{\text {bdac }}$ & $7.7^{\mathrm{dc}}$ & $27.7^{\mathrm{bdc}}$ & $3.3^{\mathrm{c}}$ & $6.7^{\mathrm{c}}$ & $2.7^{\text {ih }}$ & $232.8^{\text {ba }}$ \\
\hline $46 \mathrm{~N}-0 \mathrm{P}-0 \mathrm{~K}-0 \mathrm{~S}$ & $76.7^{\text {bdac }}$ & $8.5^{\text {bac }}$ & $37.2^{\mathrm{a}}$ & $4.7^{\mathrm{bc}}$ & $9.3^{\mathrm{bc}}$ & $2.8^{\text {ih }}$ & $225.9^{\mathrm{b}}$ \\
\hline $69 \mathrm{~N}-0 \mathrm{P}-0 \mathrm{~K}-0 \mathrm{~S}$ & $81.7^{\text {bac }}$ & $8.7^{\text {ba }}$ & $32.7^{\text {bac }}$ & $4.4^{\mathrm{bc}}$ & $8.8^{\mathrm{bc}}$ & $3.8^{\mathrm{c}}$ & $230.1^{\text {ba }}$ \\
\hline $92 \mathrm{~N}-0 \mathrm{P}-0 \mathrm{~K}-0 \mathrm{~S}$ & $80.6^{\text {bac }}$ & $8.9^{\mathrm{a}}$ & $33.9^{\text {ba }}$ & $4.7^{\mathrm{bc}}$ & $9.3^{\mathrm{bc}}$ & $3.9^{c}$ & $224.7^{\mathrm{b}}$ \\
\hline $0 \mathrm{~N}-20 \mathrm{P}-0 \mathrm{~K}-0 \mathrm{~S}$ & $76.7^{\text {bdac }}$ & $7.7^{\mathrm{bdc}}$ & $27.5^{\text {bdc }}$ & $4.5^{\mathrm{bc}}$ & $9.1^{\mathrm{bc}}$ & $3.1^{\mathrm{gfh}}$ & $241.6^{\text {ba }}$ \\
\hline $46 \mathrm{~N}-20 \mathrm{P}-0 \mathrm{~K}-0 \mathrm{~S}$ & $85.5^{\mathrm{a}}$ & $8.0^{\mathrm{bac}}$ & $29.3^{\mathrm{bdc}}$ & $6.4^{\mathrm{a}}$ & $12.8^{\mathrm{a}}$ & $5.3^{\mathrm{a}}$ & $233.3^{\text {ba }}$ \\
\hline $69 \mathrm{~N}-20 \mathrm{P}-0 \mathrm{~K}-0 \mathrm{~S}$ & $84.3^{\text {ba }}$ & $8.5^{\mathrm{bac}}$ & $31.5^{\mathrm{bac}}$ & $5.3^{\mathrm{ba}}$ & $10.7^{\mathrm{ba}}$ & $4.5^{\mathrm{b}}$ & $237.8^{\text {ba }}$ \\
\hline $92 \mathrm{~N}-20 \mathrm{P}-0 \mathrm{~K}-0 \mathrm{~S}$ & $80^{\text {bac }}$ & $8.6^{\text {bac }}$ & $31.9^{\mathrm{bac}}$ & $4.7^{\mathrm{bc}}$ & $9.3^{\mathrm{bc}}$ & $3.5^{\text {dce }}$ & $231.5^{\text {ba }}$ \\
\hline $92 \mathrm{~N}-10 \mathrm{P}-0 \mathrm{~K}-0 \mathrm{~S}$ & $77.7^{\text {bdac }}$ & $8.0^{\text {bac }}$ & $27.1^{\text {bdc }}$ & $5.1^{\text {ba }}$ & $10.1^{\mathrm{ba}}$ & $3.2^{\mathrm{gfe}}$ & $233.6^{\text {ba }}$ \\
\hline $92 \mathrm{~N}-20 \mathrm{P}-20 \mathrm{~K}-0 \mathrm{~S}$ & $84.3^{\text {ba }}$ & $8.4^{\text {bac }}$ & $33.1^{\text {bac }}$ & $5.2^{\text {ba }}$ & $10.4^{\mathrm{ba}}$ & $3.6^{\mathrm{dc}}$ & $246.4^{\mathrm{a}}$ \\
\hline $92 \mathrm{~N}-30 \mathrm{P}-0 \mathrm{~K}-0 \mathrm{~S}$ & $78.1^{\text {bdac }}$ & $8.4^{\text {bac }}$ & $31.7^{\text {bac }}$ & $4.8^{\mathrm{bac}}$ & $9.6^{\mathrm{bac}}$ & $2.8^{\text {gih }}$ & $225.0^{\mathrm{b}}$ \\
\hline $92 \mathrm{~N}-20 \mathrm{P}-10 \mathrm{~K}^{+\mathrm{R}}$ & $78.5^{\text {bdac }}$ & $8.5^{\text {bac }}$ & $33.5^{\mathrm{bac}}$ & $4.1^{\mathrm{bc}}$ & $8.3^{\mathrm{bc}}$ & $2.7^{\mathrm{i}}$ & $234.5^{\text {ba }}$ \\
\hline $92 \mathrm{~N}-20 \mathrm{P}-30 \mathrm{~K}^{+W}$ & $81.1^{\text {bac }}$ & $8.4^{\text {bac }}$ & $30.6^{\text {bdac }}$ & $4.8^{\mathrm{bac}}$ & $9.6^{\text {bac }}$ & $3.3^{\mathrm{dfe}}$ & $230.9^{\mathrm{ba}}$ \\
\hline Mean & 79.5 & 8.2 & 30.6 & 4.8 & 9.5 & 3.3 & 232.6 \\
\hline CV (\%) & 6.0 & 6.9 & 14.3 & 21.5 & 21.5 & 6.9 & 4.8 \\
\hline $\operatorname{LSD}(0.05)$ & 8.0 & 0.9 & 7.3 & 1.7 & 3.4 & 0.4 & 18.8 \\
\hline
\end{tabular}

Where: - $\mathrm{PH}=$ Plant height, $\mathrm{SL}=$ Spike length, $\mathrm{S} / \mathrm{S}=$ seed per spike, NT =number of tiller, $\mathrm{BM}=$ biomass, GY= Grain yield and TKW thousand kernel weight, nutrient rate was in $\mathrm{kg} / \mathrm{ha}$. The last three treatments the additions of micro nutrient were: ${ }^{+\mathrm{R}}=2.5 \mathrm{~S}-0.5 \mathrm{Zn}-2.5 \mathrm{Mg}-0.5 \mathrm{~B},{ }^{+\mathrm{Z}}=5 \mathrm{~S}-1 \mathrm{Zn}-5 \mathrm{Mg}-1 \mathrm{~B}$ and ${ }^{+\mathrm{W}}$ $=7.5 \mathrm{~S}-1.5 \mathrm{Zn}-7.5 \mathrm{Mg}-1.5 \mathrm{~B}$ 


\subsection{Nutrient Response Curve and Net Return Curve for Wheat}

After analysis of variance by using general nonlinear model, for nutrient response curve and Net return curve were developed from mean were used for rough estimation of optimum nutrient rate for the study area (Figure-1 \& 2). As predicted from continuous partial budget analysis, assuming minimum rate of return about $100 \%$ for unit cost, maximum net benefit of 26834.30, 20268.90 and $15290.80 \mathrm{ETB}$ was achieved at $46 \mathrm{~N} \mathrm{~kg} \mathrm{ha}^{-1}$ with $20 \mathrm{P}, 69 \mathrm{~N} \mathrm{~kg} \mathrm{ha}^{-1}$ and $23 \mathrm{~kg}$ $\mathrm{ha}^{-1}$ respectively. Similarly, an estimated wheat grain yield of $29425.50,22366.50$ and $15990.0 \mathrm{~kg} / \mathrm{ha}$ was obtained from 46 $\mathrm{N} \mathrm{kg} \mathrm{ha}^{-1}$ with $20 \mathrm{P}, 69 \mathrm{~N} \mathrm{~kg} \mathrm{ha}^{-1}$ and $23 \mathrm{~kg} \mathrm{ha}^{-1}$ respectively.

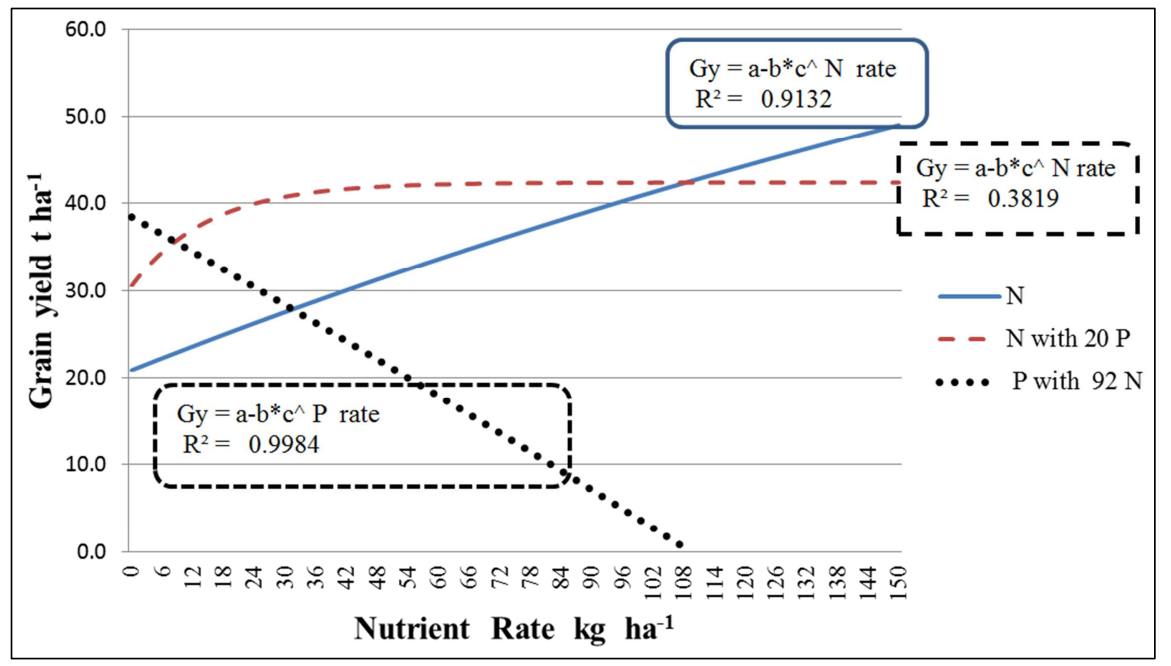

Figure 1. Nutrient Response Curve of Nitrogen and Phosphorus for bread wheat at sinana district.

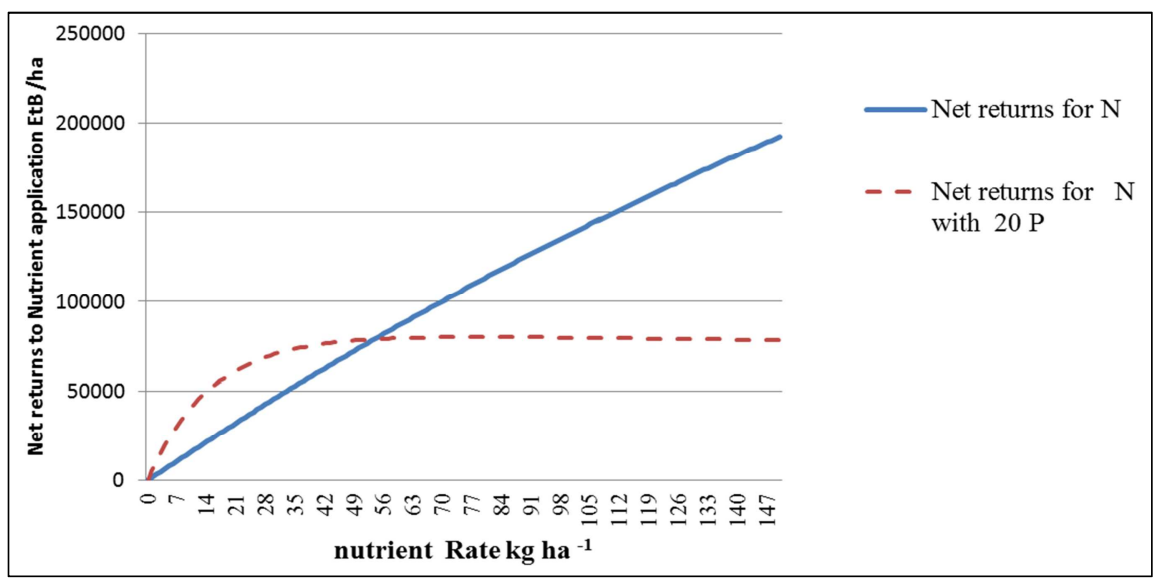

Figure 2. Net return Curve of Nitrogen and Phosphorus for bread wheat at Sinana district.

Table 3. Partial Budget Analysis of the selected treatments for the study area.

\begin{tabular}{|c|c|c|c|c|c|}
\hline Treatment & GY $\left(\mathrm{Kg} \mathrm{ha}^{-1}\right)$ & Net benefit (ETB) & Total variable cost (ETB) & Net benefit (ETB) & MRR \% \\
\hline 0N-0P-0K-0S & 12109.50 & 12109.50 & 0 & 12109.50 & \\
\hline $23 \mathrm{~N}-0 \mathrm{P}-0 \mathrm{~K}-0 \mathrm{~S}$ & 15990.00 & 15290.80 & 699.20 & 15290.80 & 454.99 \\
\hline 0N-20P-0K-0S & 18096.00 & 16903.20 & 1192.80 & 16903.20 & 326.66 \\
\hline $46 \mathrm{~N}-0 \mathrm{P}-0 \mathrm{~K}-0 \mathrm{~S}$ & 16209.38 & 14810.98 & 1398.40 & 14810.98 & $\mathrm{D}$ \\
\hline $23 \mathrm{~N}-20 \mathrm{P}-0 \mathrm{~K}-0 \mathrm{~S}$ & 21060.00 & 19168.00 & 1892.00 & 19168.00 & 119.70 \\
\hline $69 \mathrm{~N}-0 \mathrm{P}-0 \mathrm{~K}-0 \mathrm{~S}$ & 22366.50 & 20268.90 & 2097.60 & 20268.90 & 535.46 \\
\hline $46 \mathrm{~N}-20 \mathrm{P}-0 \mathrm{~K}-0 \mathrm{~S}$ & 29425.50 & 26834.30 & 2591.20 & 26834.30 & 1330.11 \\
\hline $92 \mathrm{~N}-0 \mathrm{P}-0 \mathrm{~K}-0 \mathrm{~S}$ & 18552.79 & 17853.59 & 699.20 & 17853.59 & $\mathrm{D}$ \\
\hline $69 \mathrm{~N}-20 \mathrm{P}-0 \mathrm{~K}-0 \mathrm{~S}$ & 26556.44 & 23266.04 & 3290.40 & 23266.04 & $\mathrm{D}$ \\
\hline $92 \mathrm{~N}-10 \mathrm{P}-0 \mathrm{~K}-0 \mathrm{~S}$ & 21235.50 & 19939.90 & 1295.60 & 19939.90 & $\mathrm{D}$ \\
\hline $92 \mathrm{~N}-20 \mathrm{P}-20 \mathrm{~K}-0 \mathrm{~S}$ & 16614.00 & 14722.00 & 1892.00 & 14722.00 & $\mathrm{D}$ \\
\hline $92 \mathrm{~N}-30 \mathrm{P}-0 \mathrm{~K}-0 \mathrm{~S}$ & 15537.36 & 13048.96 & 2488.40 & 13048.96 & $\mathrm{D}$ \\
\hline
\end{tabular}

$\mathrm{GY}=$ Grain yield, MRR \% = marginal rate of return in percent. 


\section{Summary and Conclusion}

Several factors limiting crop yields have been reported by many workers and the current investigation showed that application of different fertilizer type and rate contained different fertilizer source were significantly $(\mathrm{P} \leq 0.05)$ influenced almost all the crop characters tested such as height, seed per spikes, spike lengths, number of productive tillers, grain yield and 1000 grain weight. In conclusion, the result of this study showed that different nitrogen and phosphorus rates and their interaction have sound and promising impact on growth and yield of bread wheat. From this investigation the determined optimum rates of $\mathrm{N}$ and $\mathrm{P}$ fertilizers for bread wheat production was $46 \mathrm{~N} 20 \mathrm{P} \mathrm{kg} \mathrm{ha}^{-1}$ and the effects of $\mathrm{N}$ and $\mathrm{P}$ fertilizer applications on yield and yield components was clearly observed. The maximum grain yield $\left(5.3 \mathrm{t} \mathrm{ha}^{-1}\right)$ was obtained at the rate $\left(46 \mathrm{~N} 20 \mathrm{P} \mathrm{kg} \mathrm{ha}^{-1}\right)$ which show an increment of $53.5 \%$ yield advantage over than the control and $9.74 \%$ the next higher yield under the treatment contained $\left(69 \mathrm{~N} 20 \mathrm{Pkg}^{-}\right.$ $\left.{ }^{1}\right)$. Therefore, on the basis of the results of the present study, it is indicative that better yield advantage obtained at Selka Oda and farmers can benefit more by using $46 \mathrm{~kg} \mathrm{ha}^{-1}$ of nitrogen in combination with $20 \mathrm{~kg} \mathrm{ha}^{-1}$ phosphors which economically feasible. As a conclusive remark, the result of the current study provide basic information for further research and development efforts in soil fertility management for sustainable utilization of the soil resources in the area.

\section{Acknowledgements}

First and for most we would like to thank AGRA SHP for supporting for financial support. We acknowledge Dr. Negash Demissie and Mr. Dereje Regassa for their continuous follow up and monitoring leading for the rewarding final output of the experiment. Extend special thanks to Oromia Agricultural Research Institute (OARI) for his valuable collaboration work with all stakeholder, thanks are given to Sinana Agricultural Research Center for providing logistic support as well as Soil Fertility Improvement, Soil and Water Conservation technology generation team for success full conduct the experiment and field work assistance.

\section{References}

[1] Amanuel Gorfu, Kefyalew Girma, D. G. Tanner, Asefa Taa, and Shambel Maru, 2000. Effect of crop rotation and fertilizer application on wheat yield performance across five years at two locations in southeastern Ethiopia. pp. 264-274. In: The Eleventh Regional Wheat Workshop for Eastern, Central and Southern Africa. CIMMYT, Addis Ababa, Ethiopia.

[2] Amsal Tarekegn and D. G. Tanner, 2001. Effects of fertilizer application on $\mathrm{N}$ and $\mathrm{P}$ uptake, recovery and use efficiency of bread wheat grown on two soil types in central Ethiopia. Ethiopian Journal of Natural Resources. 3(2): 219-244.

[3] Amsal Tarekegn, D. G. Tanner and Chanyalew Mandefro,
2000. Agronomic and economic evaluation of the farm $\mathrm{N}$ and $\mathrm{P}$ response of bread wheat grown on two contrasting soil types in central Ethiopia. pp. 239-252. In: The Eleventh Regional Wheat Workshop for Eastern, Central and Southern Africa. CIMMYT. Addis Ababa, Ethiopia.

[4] Amsal Tarekegn, D. G. Tanner, Amanuel Gorfu, Tilahun Geleto, and Zewdu Yilma, 1997. The effect of several crop management factors in bread wheat yields in the Ethiopian highlands. African Crop Science Journal. 5: 161-174. Archer, J., 1988. Crop Nutrition and Fertilizer Use. Farming Press Ltd. Suffolk. 265p. Asgelil Dibabe, Andualem Taye and Sahlemedhim Sertsu, 1993.

[5] Asif, M., M. Maqsood, A. Ali, S. W. Hassan, A. Hussain, S. Ahmad, et al. 2012. Growth yield components and harvest index of wheat (Triticum aestivum L.) affected by different irrigation regimes and nitrogen management strategy. Science International (Lahore) 24: 215-218.

[6] Asnakew Woldeab, Tekalign Mamo, Mengesha Bekele and Tefera Ajema, 1991. Soil fertility management studies on wheat in Ethiopia. pp. 137-172. In: Hailu Geberemariam, D. G. Tanner and Mengistu Hulluka (Eds.). Wheat Research in Ethiopia: A Historical perspective. IAR/CIMMYT, Addis Ababa, Ethiopia.

[7] Baethgen, W. E. and M. M. Alley. 1989. A manual colorimetric proce- dure for measuring ammonium nitrogen in soil and plant kjeldahl digests. Commun. Soil Sci. Plant Anal. 20: 961-969.

[8] Ejaz, H., W., Alishah, A. A. Shed, F. Hayat and J. Bakht, 2002. Yield and yield components of wheat as affected by different planting dates, seed rates and nitrogen levels. Asian Journal of plant science. 1 (5): 502-506. El-Karamity, A. E., 1998. Response of some wheat cultivars to seeding and nitrogen fertilization rates. Environment. 22: 859-866.

[9] Ferguson RB, Hergert GW, Schepers JS, Gotway CA, Cahoon JE, Peterson TA. 2002. Site-specific nitrogen management of irrigated maize: Yield and soil residual nitrate effects. Soil Science society American Journal, 66: 544-553.

[10] Fisher, R. F. and D. Binkley, 2000. Ecology and management of forest soils, 3rd (Ed.). John Wiley \& Sons, Inc., New York. 489p. Fisseha Itana, 1992. Macro and micronutrients distributions in Ethiopian Vertisols landscapes. $\mathrm{PhD}$ Dissertation, University of Hohenheim, Germany. 201p. Foth, H. D., 1990. Fundamentals of soil science. 7th (Ed.). John Wiley and Sons, Inc., U.S.A. 435p.

[11] Hussain, I., M. A., Khan and E. A. Khan, 2006. Bread wheat varieties as influenced by different nitrogen levels. 7(1): 7078. http://www.zju.edu.cn/jzus Online. Hussins, D. R. and W. L. Pan, 1993. Nitrogen efficiency components analysis: An evaluation of cropping system difference in productivity.

[12] Lopez-Bellido RJ, Lopez-Bellido L. 2001. Efficiency of nitrogen in wheat under Mediterranean condition: effect of tillage, crop rotation and $\mathrm{N}$ fertilization. Field Crop Research. 71(1): 31-64.

[13] Power JF, Wiese R, Flower day D. 2000. Managing nitrogen for water quality: Lesson from management systems evaluation area. Journal of Environment, 29: 335-366.

[14] Rahimizadeh M. 2010. Nitrogen use efficiency of wheat as affected by preceding crop, application rate of nitrogen and crop residues. Australian Journal of Crop Science, 3: 89-93. 
[15] Rahmati H. 2009. Effect of plant density and nitrogen rates on yield and nitrogen use efficiency of grain corn. Would Applied Science Journal, 7(8): 958-961.

[16] Tilahun Geleto, Tanner, D. G., Tekalign Mamo and Getinet
Gebeyehu. 1996a. Response of rainfed bread and durum wheat to source, level and timing of nitrogen fertilizer at two Vertisol sites in Ethiopia. pp. 127 -147. In: The Ninth Regional Wheat Workshop for Eastern, Central and Southern Africa. Addis Ababa, Ethiopia: CIMMYT. 